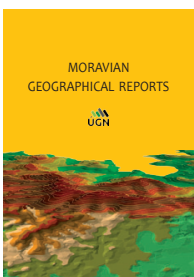

\title{
The dynamics of population distributions in cities based on daily mobile phone operations: A case study of some Moravian cities
}

\author{
Gabriel KOPÁČIK a * , Antonín VAISHAR ${ }^{\text {a }}$ Eva ŠIMARA a
}

\begin{abstract}
Analyses of the changes in the presence of persons in different central and residential parts of urban areas are subject to evaluation in this paper. Case studies of the cities of Brno, Ostrava and Zlin during the day and night are highlighted. Data from a provider of mobile phone services were used for the analyses. It appears that the data can be important for the comparison of different urban structures. The results demonstrate that the organisation of urban structure affects the number of visitors and thus the area attractiveness. It was confirmed that the number of mobile phone users in the city cores is higher than the number of permanent residents. The greatest differences between the day and night in the city cores were found in Brno, a concentric city with the most important central functions among the cities studied. Differences between the day and night in residential areas were not as large as expected. City neighbourhoods in Brno showed some specific rhythmicity.
\end{abstract}

Keywords: day/night population dynamics, mobile services providers, urban structures, Brno, Ostrava, Zlín, Czech Republic.

Article history: Received 27 May 2019, Accepted 1 December 2020, Published 31 March 2021

\section{Introduction}

As a rule, population data have a static character. They are valid at a certain moment in time and usually relate to permanent residents. Although in the last Czech census the concept of usual residence was introduced, most people probably still declared their responses in relation to their permanent residence ${ }^{1}$. For larger cities, residents are concentrated normally in residential quarters and suburbs, whereas city cores have lost permanent inhabitants in favour of commercial and office facilities. A significant part of commercial activities has moved from historic centres to shopping malls on the outskirts of cities as well. In general, it can be stated that the greatest changes have been experienced in city centres and some parts of inner cities on the one hand, and in the city outskirts on the other hand (Horská et al., 2002).

It is quite difficult to capture or explain such a situation by using common statistical methods. Understandably, any observation made by humans would be extremely demanding: hence, other methods are looked for. Using the data about movement of mobile phones by network operators and its application to the territory of cities is one of the options. According to Järv et al. (2018), current models of location-based accessibility are often atemporal in nature. Locations of persons, transport and service supplies may change dramatically within 24 hours. The observation of population changes within a certain territory was introduced by Hägerstrand in the 1960s under the concept of time geography (Brauer and Dimitroff, 2017).

Using statistical data, city cores seem depopulated, whereas suburbs are rapidly growing. The changes were confirmed by Sýkora et al. (2000). It is known, however, that people frequently move across the city territory within a day. It is necessary to add persons who move between the city and its hinterland, students and tourists. It follows that the displacement of people within the city territory can be quite differentiated in the day and in the night, and different from the number of permanent residents. It is extremely

\footnotetext{
${ }^{a}$ Faculty of Architecture, University of Technology Brno, Czech Republic (*corresponding author: G. Kopáčik, e-mail: kopacik@fa.vutbr.cz)
}

\footnotetext{
${ }^{1}$ All persons with addresses registered in the Information System of Population Registration are considered permanent residents. Place of usual residence is defined as the place where a person usually spends his/her daily rest period regardless of temporary absence due to recreation, visits, business trips, stay in a medical facility, etc. and where the person is a member of specific household.
} 
important for urban planning because the infrastructure of all city parts should correspond to the maximum number of people staying in individual parts - not to permanent residents only.

Some parts of the city can be predominantly residential, some are predominantly working quarters and yet other ones can be of mixed nature. Opinions on such a division differ. Some theories prefer a strong functional division of the city; others prefer a mixture of functions. It is said that one-sided profile city parts could be dangerous during the day when they are half-empty (working quarters at night, residential quarters during the day), whereas mixed quarters are relatively safer (Marques et al., 2018).

There are many city structure theories from ancient cities to Thomas More's Utopia. In the last century, town planning was affected by the Athens Charter (1933), for example. Its main idea consisted in the separation of three city functions - residential, industrial, and recreational, which were interconnected by the fourth function transport. Although the Athens Charter has never been fully implemented, the territorial division of functions exists more or less in each city. Because there are not only one-functional but also multifunctional quarters, however, the situation is more complicated than the Athens Charter presupposed. It follows that monitoring population movement in city areas is meaningful and important.

An attempt on updating the Charter was made in 2003, taking into account new factors such as security, health, innovation, environment, etc. A key factor in our investigation is yet another one - accessibility. The new vision consists of a polycentric structure and connectivity. Population densities change during the day and this represents one of the most important factors in information for its evaluation. ICT technologies represent a suitable tool (Fernandez-Maldonado, 2012).

Identification of regularities in the daily rhythmical changes of population are the subject of evaluation in this paper, using case studies of three Moravian cities. The changes were investigated in relation to the functions of individual city parts. The research was focused on the comparison of cities with similar socio-economic conditions, but with a different historical development of their urban structures. At an application level, the results could be used to design an optimal urban structure in the planning of technical infrastructure, public transport connections, but also for the purposes of personal security or forensic purposes. The paper was created as part of a wider study examining "The impact of urban structure character and location on the sustainable development of the territory." Various qualitative indicators of sustainable development were monitored in the characteristic urban structure fragments. The number of mobile network users was one of those indicators.

\section{Theoretical background}

\subsection{Rhythmicity of urban spaces}

Space and mobility are phenomena interacting in the construction of the contemporary world at and across many geographical scales - including the urban one (Simonsen, 2004). The concept of regular changes in population density in an urban area is based on Lefebvre's theory of rhythm analysis first published in 1992 (Lefebvre, 2004). The substance of the concept consists in frequency measurement. All interactions between time, place and energy expenditures exhibit a rhythm. It might consist in the repetition of some processes, in interferences of processes and/or in the processes of birth and dying. According to Edensor (2010): "in terms of geography, the rhythm analysis highlights tensions between repetition and innovation, between the need for consistency and the need for disruption".

The problem of space, time and city based on Lefebvre's theory and its validity for the current century has been discussed for example by Simonsen (2004). Reid-Musson (2017) used Lefebvre's theory to investigate the everyday life of migrant farmers in rural Canada. She states that "rhythms help produce unequal subject positions of migrants in Canada, yet also represent lived uses of space and times which permit transgressions of racial, gender, and class boundaries". The spatio-temporal relation in human geography, using rhythm theory, was also highlighted by Mels (2004).

Rhythmicity has been changing over time in relation to the development of technologies. In pre-industrial stages, the place of work was more or less the same as the place of residence for the majority of people, who moved for some shopping or religious reasons only. Rhythmicity in the urban territory (which was much smaller than today) occurred only at a lower frequency and at a shorter distance. Originally, also in times of industrialisation, dwelling places of workers used to be built near factories or mines. Such an organisation of the urban territory began to change in the last century when individual functions of the city started to be divided - partly due to environmental reasons. Also, human activities became specialised: besides work and dwelling, new activities started to appear relating to leisure time. Public transport allowed for easier and more frequent movement within the urban territory. Ideas about the division of functions found their expression in the Athens Charter (1933). It evoked frequent rhythmicity across longer distances.

After the Second World War, the division of work and residential places found its expression in suburbanisation, which shifted the rhythms towards the city-hinterland relation - together with the rhythmical relation between first and the second residences. From rural areas, commuting for work brought rhythmical movements to urban territories. Urban rhythmicity, however, was still determined by residence-workplace relations. Industrial areas with thousands or dozens of thousands of employees on the one hand, and large residential areas (represented mostly by prefabricated estates) on the other hand, were the main aims and sources of the movements, which was expressed also in the organisation of municipal transport. A picture of overloaded vehicles of public transport heading from housing estates to industrial zones in the morning and in the opposite direction in the evening, were typical of industrial cities.

The post-productive era and globalisation (understood as a post-socialist era by some authors) brought about another substantial change in rhythmicity. For instance, Mulíček and colleagues (2016) analysed daily rhythms in Brno in the light of changes from a productive to a post-productive society using metropolitan transport services, showing a change of hotspots from large industrial plants to hospitals, universities, commercial centres and consumption-oriented places, which are more dispersed across the urban territory. Non-productive functions became not complementary but rather independent. Osman and Mulíček (2017) combined 
Lefebvre's concept of rhythmicity with Laguerre's concept of chronopolis (2003), reconceptualised on a city-scale level, describing 18 city areas of Brno. Mulíček and Osman (2018) have evaluated urban rhythmicity in relation to shopping activities. The increasing amount and importance of leisure time has also engendered mobility for social life, entertainment, and recreation. Moreover, except for their own city and its hinterland, people travel to a much wider extent. These rhythmical movements have different driving forces, different daily and seasonal courses, and different participants.

Many of these references relate to the methodology itself, however, rather than to the clarification of 'observed facts' and to the identification of possible relations between the movement of persons and the urban structure of cities, a paper by de Nadai et al. (2016) being one of the rare exceptions. Additionally, Louail et al. (2014) showed, using the case of large Spanish cities, how hotspots (points of the high concentration of people) can be delimited, their changes during the day and relations among them. The methodology of these authors resulted in a typology distinguishing between monocentric and polycentric cities. For forensic purposes, Malleson and Andresen (2015) tried to put together the concentration of persons with places of frequent street crimes to estimate the risk of robbery. Similarly, Smith and Hall (2013) observed the circadian rhythms of urban street police in Cardiff. The development of digital technologies allows the use of data of mobile services providers in monitoring population dynamics (Deville et al., 2014; Grauwin et al., 2014; Steenbrugger et al., 2015).

Similar research was realised by Novák and Temelová (2012) in Czech conditions. Their paper combined digital data with interviews aimed at understanding the mechanisms of movements of young people across the city territory. Silm et al. (2013) investigated differences between genders in the daily movement of people in the territory of Tallinn using similarly a combination of mobile phone data and interviews. Šveda and Barlík (2018) used mobile positioning data to investigate daily commuting in the Bratislava metropolitan area with a similar aim, namely, to reveal disproportions between permanent residence and real living. The above-mentioned papers have largely been aimed at the methodological aspect of the identification of daily movement of people across urban areas.

In terms of time, it is possible to investigate daily rhythms (day/night differences), weekly rhythms (weekdays/weekend days), annual rhythms (considering tourist seasons, school years, etc.) or special rhythms which could consider special events. In our research, we focussed on the day/night rhythms. This kind of rhythm is connected mostly with the cycle of <dwelling - working (or education) - daily leisure - dwelling >. Pasqui (2016) characterised the temporary population as "groups of subjects that, temporarily and intermittently, share practices of daily life". Such cycles concern mainly people of productive age and students although other population groups participate as well. Lager et al. (2016), however, showed that the rhythms of seniors are different. From viewpoint of an individual, however, daily rhythms partly result from a feeling or habit rather than from a rational decision, and in such a way they relate to sociocultural conditions (Neuhaus, 2014).

\subsection{Urban structure}

The spatio-temporal relations in urban areas relate to the functions of individual urban structures and their localisation within the territory. Individual structural parts change their functions from the source to the target of population movements during the day. The population of a productive city is distributed mainly between residential quarters and industrial areas during the working days. The situation in a post-productive city is more differentiated. The following aspects can play a role: a wider distribution of workplaces within the urban territory; some people working from home; an increasing share of pensioners with a different style of work; the increasing amount and importance of leisure activities; the increasing role of consumption of diverse types; current urbanisation processes, namely suburbanisation and gentrification; and the increasing social differentiation of cities.

In the last few decades, opinions prevailing among urban planners is that an ideal city is a compact city, a city of short distances. This ideal has two characteristics: tightness, the city should be as tight as possible, minimising the occupation of agricultural land and landscape, and a diversity of functions in the territory. Such a structure should be more economical and more sustainable in the long run, as Jacobs (1970) stated years ago. Real urban development, however, does not always correspond to this. On the one hand, a city block is being constructed as an urban manifesto, called "Compact City" (BUS, 2003), and on the other hand, a developer project with detached houses in greenery called "Greene Schanze" is being built right next to it on the same street (two recent realisations in the Vienna district of Floridsdorf, see Matyášová, 2019). One ideal of urban planners is a multifunctional inner city, but people are moving to monofunctional satellites situated beyond the city limits (Hnilička, 2012). Even the socialist panel housing estates do not have to lose their attractiveness (for example, Lesná in Brno: Wittmann, 2017). The decreasing population and the outflow of business activities moving to large shopping areas on the city outskirts increase the risk of a decline of city centres (IPR, 2016; Slach and Nováček, 2017) ${ }^{2}$. There are also expert articles that put the ideal of a compact city into question (Neuman, 2005). In the end, however, people vote on the quality of a city and its parts by their presence (Gehl, 2011). From this point of view, it seems useful to monitor and compare the occurrence and movements of people in different parts of cities and in different types of cities. Large numbers of people in a locality show that the locality is attractive to visitors, as much as the absence of people in a built-up urban area during some parts of the day can be seen as a pathological phenomenon.

Spatio-temporal relations in the studied cities are developing significantly in connection with the transition to a market economy, post-industrial (consumer) society and with the changing conditions of intra-city transport, online work and services. Moreover, the rapidly evolving situation needs to be monitored and generalised at various stages of development. On the other hand, new technologies also allow for a methodological shift. For example, Kubíček et al. (2019) analysed changes in the presence of the population in Brno via mobile phones for the needs of crisis management. Using an example of the five largest Australian cities, Coffee, Lange, and Baker (2016) stated that city cores were rapidly

\footnotetext{
${ }^{2}$ The official population census indicates that in the period from 2001-2011, the historic cores of Brno, Ostrava and Zlín lost 8\%, $18 \%$ and $11 \%$ of inhabitants, respectively.
} 
losing population in favour of the fringes in the 1980s. Later, some parts of the inner cities were selectively re-urbanised. Which stage of this process are Moravian cities at? This paper attempts to analyse urban structure optimisation in the contemporary processes of urbanisation.

\section{Data and methods}

\subsection{Cities under investigation}

Three cities were selected for our comparative study: the largest Moravian city of Brno, the second largest Moravian city of Ostrava, and the regional city of Zlín (Fig. 1). The analysis was performed for basic settlement units (ZSJ) ${ }^{3}$, the smallest units for which public data were available. Each unit was assigned a predominant type of urban structure so that it was possible to identify the occurrence of the observed phenomenon in relation to the type of urban structure. ${ }^{4}$

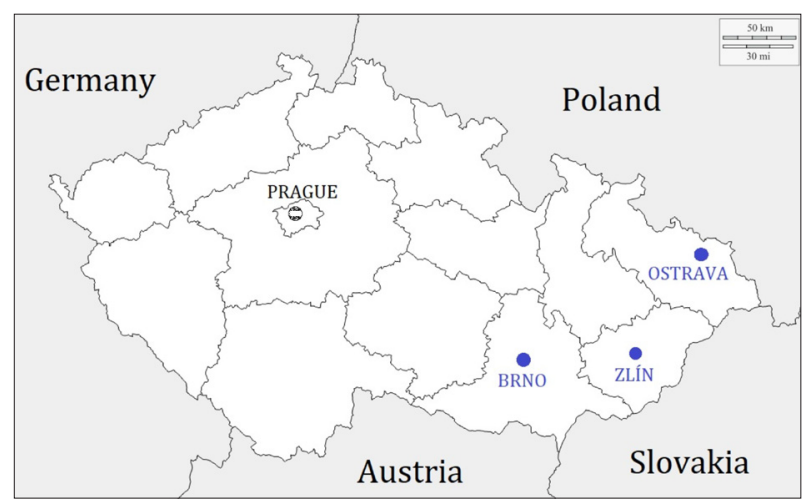

Fig. 1: The location of investigated cities in the Czech Republic

The following types of urban structures were delimited in the cities under investigation:

- Central block (A) - compact historic cores with medieval foundations and the linked-up block structures from the end of the $19^{\text {th }}$ and beginning of the $20^{\text {th }}$ centuries;

- Suburban block (B) - regular block structure outside the city centre, usually realised before the $1950 \mathrm{~s}$;

- Unordered urban area (C) - the area of disordered urban structures, consists of a combination of block and free housing structures with buildings of various functions from different times, which could not be classified with the other groups;

- Two-year plan buildings (D) - specific post-war structures from the turn of the 1940s and 1950s, represents a specific type because of the characteristic linear arrangement of apartment buildings;

- Villa quarters (E) - usually detached apartment buildings (villas) in greenery: Bata houses in Zlín from the period between the wars represent a typical form of such structures;

- Prefab housing estates (F) - housing estates outside the inner city, contain mainly apartment buildings constructed by using prefabricated technology in the period of socialism from the end of the 1950 s to the beginning of the 1990s;

- Family houses (G) - areas of detached houses occupied by family houses from different time periods (mostly from the $19^{\text {th }}$ to the $21^{\text {st }}$ century); and

- Other: public infrastructure - storage, manufacture, services - forests and parks - agricultural land - water areas and streams.

The selected cities represent very different cases. Brno has been growing since the $13^{\text {th }}$ century when individual urban styles and concepts evolved organically and gradually relied on themselves. Ostrava is a rapidly and chaotically growing city, originally based on coal mining and the development of heavy industries. Zlín is a 'company town' (Jemelka and Ševeček, 2013) built according to a unified urban plan under the influence of the Athens Charter.

Brno is the second largest city in the Czech Republic and the regional centre of Moravia. It has about 380,681 inhabitants (end of 2018, Czech Statistical Office). The current population, however, can be estimated at more than half a million, including foreigners with long-term residence permits, university students (about 75,000 students, a majority of them coming from other places), commuters, etc. Since the $13^{\text {th }}$ century, the city has been an important centre of commerce, education, culture, and later a node of industries, a transport junction, the seat of administration and justice. The most intensive city structure development is connected with industrialisation in the $19^{\text {th }}$ century, and later with the establishment of Czechoslovakia after 1918 (Kuča, 2000). The socialist period was characterised by the construction of prefabricated residential quarters; the period after 1990 has been affected by suburbanisation, gentrification and reconstruction (Sýkora and Ouředníček, 2007).

Ostrava with the population of 289,100 inhabitants (end of 2018, Czech Statistical Office) was originally twin towns and other settlements in the peripheral location on the Moravian-Silesian border, divided by the Ostravice River into Moravian Ostrava and Silesian Ostrava. The topography at the confluence of four rivers is flat. In 1763, black coal was discovered in the region. In relation to the later industrial revolution, it resulted in a stormy development. The logic of urban fabric formation, however, was different than that of Brno. Individual mines were the main points of activities. They were surrounded by worker colonies, the factories of heavy industry, mine heaps and the related infrastructure. In this way, a mixture of mines, infrastructure, residential areas and other facilities was created. The city experienced heavy environment pollution and in the productive era, Ostrava became "a steel heart of the country". Mining activities intensified. Industrial development was accompanied by the mass construction of prefabricated housing estates, forming realistic new towns - partly as a substitution for undermined areas. As a result, Ostrava has in fact more city centres - the historical one, which is relatively small,

\footnotetext{
3 The "basic settlement unit" (in Czech "základní sídelní jednotka" - ZSJ) - is a basic component of residential units defined in the Czech Republic by law in the state statistical office. The unit is smaller than a quarter or district, is clearly delimited in the territory, often represents a block of houses bordered by the surrounding streets, and it is primarily used for the statistical monitoring of socio-economic and territorial-technical phenomena.

${ }^{4}$ Apart from mobile phone users, we monitor various other social and environmental phenomena in the defined types of urban structures over a long period such as population structure, prices of real estate, air temperatures, etc. (Kopáčik and Vaishar, 2020; Wittmann and Kopáčik, 2019; Kopáčik and Kilnarová, 2018).
} 
and the cores of new quarters. A different social structure was created, characterised by people with low qualifications but high salaries. The city acquired a negative image both in environmental and social terms. It is part of a relatively continuous urban belt stretching into Poland. After 1989, the national economy turned away from heavy industries and coal mining in Ostrava was brought to end in 1994. The city and its surroundings were affected by structural changes. The demographic situation was characterised by emigration to surrounding small towns and villages (Vaishar, 2002). One can speak of a shrinking city (Rumpel and Slach, 2012), but regardless of the decreasing population numbers, the city remains an important regional centre with developing educational and cultural functions.

The post-socialist changes in the inner structure of Brno and Ostrava as examples of second-order cities were described by Bierzyński et al. (2011), including their population development and taking into account the housing market conditions. Zlín with a population of 75,000 inhabitants (end of 2018, Czech Statistical Office) is situated in a narrow valley of the Dřevnice River, dividing the Hostýnské vrchy Hills and the Vizovické vrchy Hills. This geographical situation predetermines the belt-like inner structure of the city. Zlín was a small town until the end of the $19^{\text {th }}$ century. In 1894, Antonín Bata founded his shoe factory, which became the base for a later expansion to the whole world. Huge development was recorded from the 1920s. The Bata Company built not only the large factory with its infrastructure, but also a city for about 50,000 inhabitants. A myth came into existence of the living Utopia (Vacková and Galčanová, 2009). The city was an example also for some European urban planners (Abramson, 2009). The factory replaced the main square functioning as a city centre. Quarters of detached houses grew up on the valley slopes, while the valley itself was built with public buildings, a majority of which belonged to or were connected with the Bata Company. The company was nationalised in 1945 along with key industries. A prefabricated housing estate called Jižní svahy (Southern Slopes) was built for the increasing number of workers. After 1989, the main company collapsed due to unpaid receivables from countries of the former USSR. The city agglomeration is limited by its location in a relatively deep valley. In fact, Zlín forms a belt city with the neighbouring former village of Otrokovice.

All three selected cities are similar in that they are in the same post-socialist socio-political situation and at the same post-industrial stage of their development, they are all regional centres, three of the four largest Moravian cities. What differentiates them, however, is urban structure and arrangement, each one of them representing a different and relatively distinct urban concept. It turned out to be an opportunity to observe how these different physical arrangements affect city life, how they affect the area attractiveness, as measured by the frequency and movement of people. Today, a new option is offered for tracking people in the city - through their mobile phones.

\subsection{Database of mobile network operators: $A$ tool for studying urban population movements}

The 02 Czech Republic mobile network operator temporarily allowed access to the open data of mobile phones on their website in the form of the API (Application Programming Interface) demo interface $(\mathrm{O} 2,2018)$. These data were provided in the beta version and were published every Wednesday, with information about phone traffic from
Monday of the same week. Unfortunately, there were no other weekdays when the data were released in the beta version except for those of Mondays. The mobile network operator uses one of the network base techniques that gathers data as a side effect of the connection of individual phones to the telecommunication network provided by the transmitter tower (BTS) (GSM web, 2018). The phone is usually mostly responding to the transmitter with the strongest signal and can be located by any common signal strength triangulation method in between several transmitters which it is responding to; there are no Call detail records (CDR) data used (Whitehead, 2008). The more transmitters, the more accurate is the user's location. As there are usually more transmitters in the city centres and urban areas, the mobile network operator claims the accuracy of the geospatial position user to be up to 100 metres. In the outskirts of the cities and in rural areas, the accuracy is lower and varies, depending on the density of transmitter towers (Laitinen et al., 2001). The data obtained in this manner are from one mobile network operator and are extrapolated to the whole population. The operator claims that machine-to-machine SIM cards, for example for Internet of Things (IOT) devices, and SIM cards from state institutions are discarded from the data sample $(\mathrm{O} 2,2018)$. Those data have been converted by using the common type of triangulation to the system of basic settlement units. The operator does not specify the type of triangulation as it is a subject of competitiveness among various operators.

The data available through the socio demo API were divided into transfer data, showing the number of phone users travelling through the unit in a selected hour of the day, and visitor data, showing the number of phone users staying in the selected unit and hour for more than 30 minutes. The API interface provides separate numbers of male or female users per the selected hour, or a division of users according to age groups defined as 8-18 years, 19-25 years, 26-35 years, $36-55$ years and $56+$ years in the chosen hour. If the number of phone users (either males or females, or age group as defined in the API) in the selected basic territorial unit is below 100, no data are displayed because of data anonymization, which means that there are no data provided for units with less than ca. 200 users in the given hour (males + females).

The selected data are average values from Mondays in May 2018. They are from the socio demo API containing information about the total number of users who stayed in the units for more than 30 minutes. Those numbers were gathered into a SQL database and converted into a table. Day averages for the period from 06-18 o'clock and night averages for the period from 22-06 o'clock were counted (Horáková, 2018). The outputs can show the density of mobile phone users per 1 ha, which allows for a better comparison among the units of different size.

Mobile phone user data seem to be quite useful for monitoring activities in the basic settlement units (ZSJ). These data cannot be fully associated with a real number of individuals in the urban area but are directly proportional. A higher number of mobile phone users means a higher number of persons in the area and vice versa. The higher number of persons then testifies to the greater attractiveness of the area (Gehl, 2011), because a public urban space without people is not a quality urban space (Jacobs, 1961)

There are some specific characteristics and limitations to expect when working with the beta version data: 
- Mobile phone users are aged over 8 years, with an active phone device, who spent more than 30 minutes in a certain basic territorial unit. The number of phone users does not include machine-to-machine or state institution SIM cards. The mobile network operator claims that the data include users from the whole population sample, i.e. all users covered by all mobile network operators and not only by $\mathrm{O} 2$ Czech Republic;

- Due to data anonymization, basic territorial units with fewer than 200 users (100 female users +100 male users) are marked as 0 users. Those units are pictured as 'no information' in images attached to this paper;

- The number of phone users varies within the basic territorial units, the mobile network operator claiming an accuracy of about 100 metres. The boundary lines of basic territorial units and the BTS network do not necessarily match, which means that there are inaccuracies in the triangulation method, especially in rural areas with a lower density of transmission towers. Regardless, daily rhythms of users' movements are still of some significance;

- The mobile network operator provided neither its complex method of data collection, nor the exact type of triangulation due to competitiveness reasons;

- The data represent an ordinary sunny Monday (May, 2018); we are aware that Monday may not be the best characteristic day of the week, unfortunately, there were no other weekday data available in the API beta version; and

- The aim of the paper is to highlight common tendencies of phone users' movements in the urban area. Further research is needed to corroborate the final results of our study, which would call for greater collaboration on the part of mobile network operators and their willingness to release data from other weekdays to be used for comparison.

\section{Results and discussion}

\subsection{Population distribution changes in Brno, Ostrava and Zlín during the day}

In Brno (see Fig. 2), the highest density of mobile phone users per ha can be found in ZSJ units situated in the city core. In these quarters, a peak density occurs at noon. Very high densities are typical also for the inner city, both in areas of lower social level with partly deprived populations and in those of higher social status. Peaks occur in different parts of the day: in the morning or in the afternoon. Areas with the highest density of persons can be found exclusively in compact, multi-functional block structures in the centre and in the inner city of Brno. Cores of prefabricated housing estates on the outskirts of the city are less attractive (see Fig. 2), likely a consequence of the concentric organisation of the city with a dominant centre, and a result of the higher importance and attractiveness of Brno as compared to Ostrava and Zlín.

Similarly, the highest density of mobile phone users in Ostrava (Fig. 3) during the day was observed in the central city parts at noon; in areas with a higher social infrastructure, the highest population density was recorded at 10 a.m., but the density of people was lower than that in Brno, as not all of the mentioned units are of compact block structure. The Fifejdy Hospital is a hospital area, whereas Karolina is a modern shopping mall with quite new apartments. The

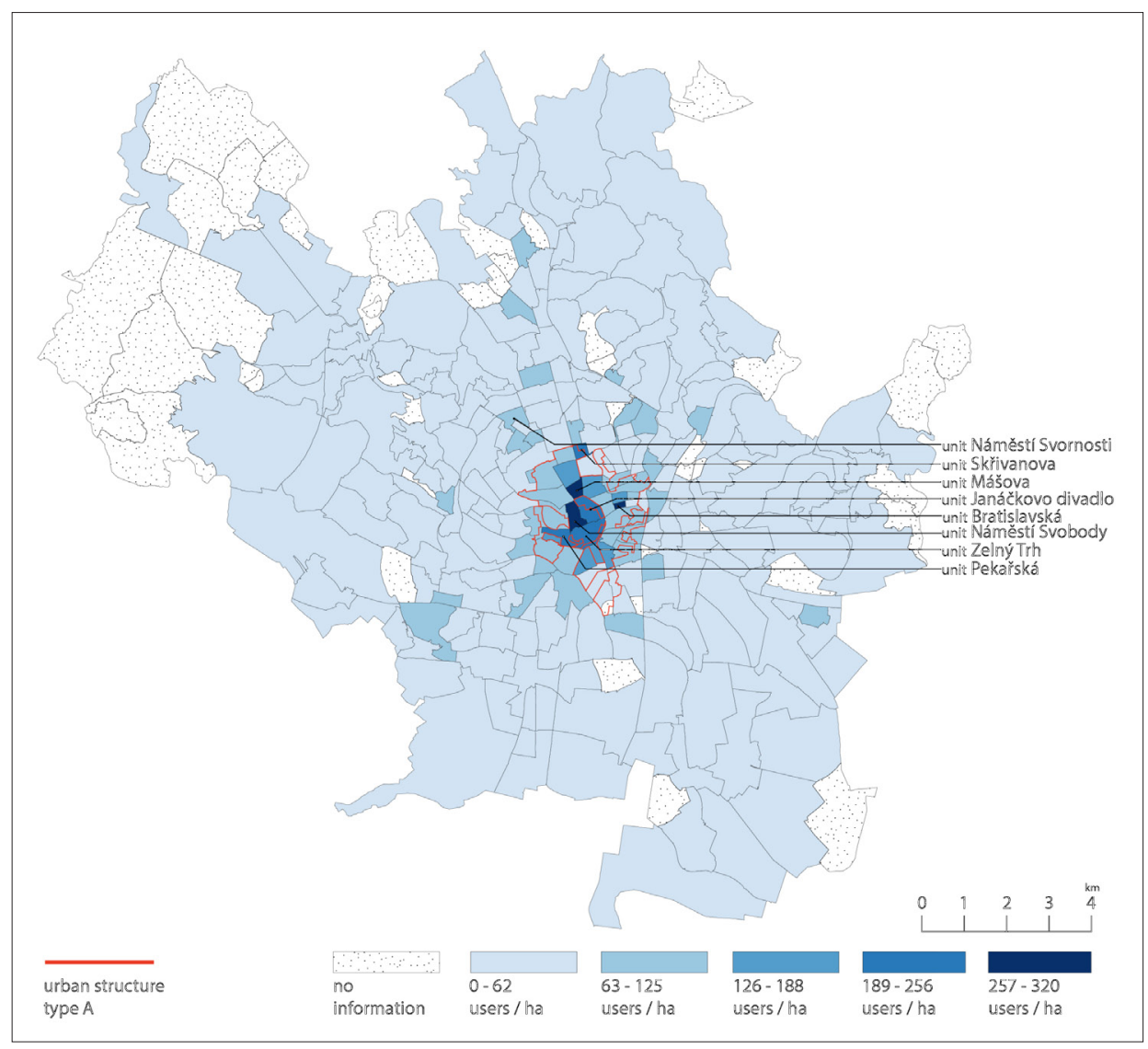

Fig. 2: The attractiveness of individual basic settlement units (ZSJ) in Brno during the day, according to the mobile network operator, May 2018. Source: O2 Czech Republic, authors' elaboration 
attractiveness of prefabricated estates is similar to that in Brno; therefore, differences between the central parts and the prefabs are not so distinct.
The lower attractiveness of central parts in Ostrava is conditioned probably by the lower land use intensity (lower buildings, lower density of permanent residents), by the

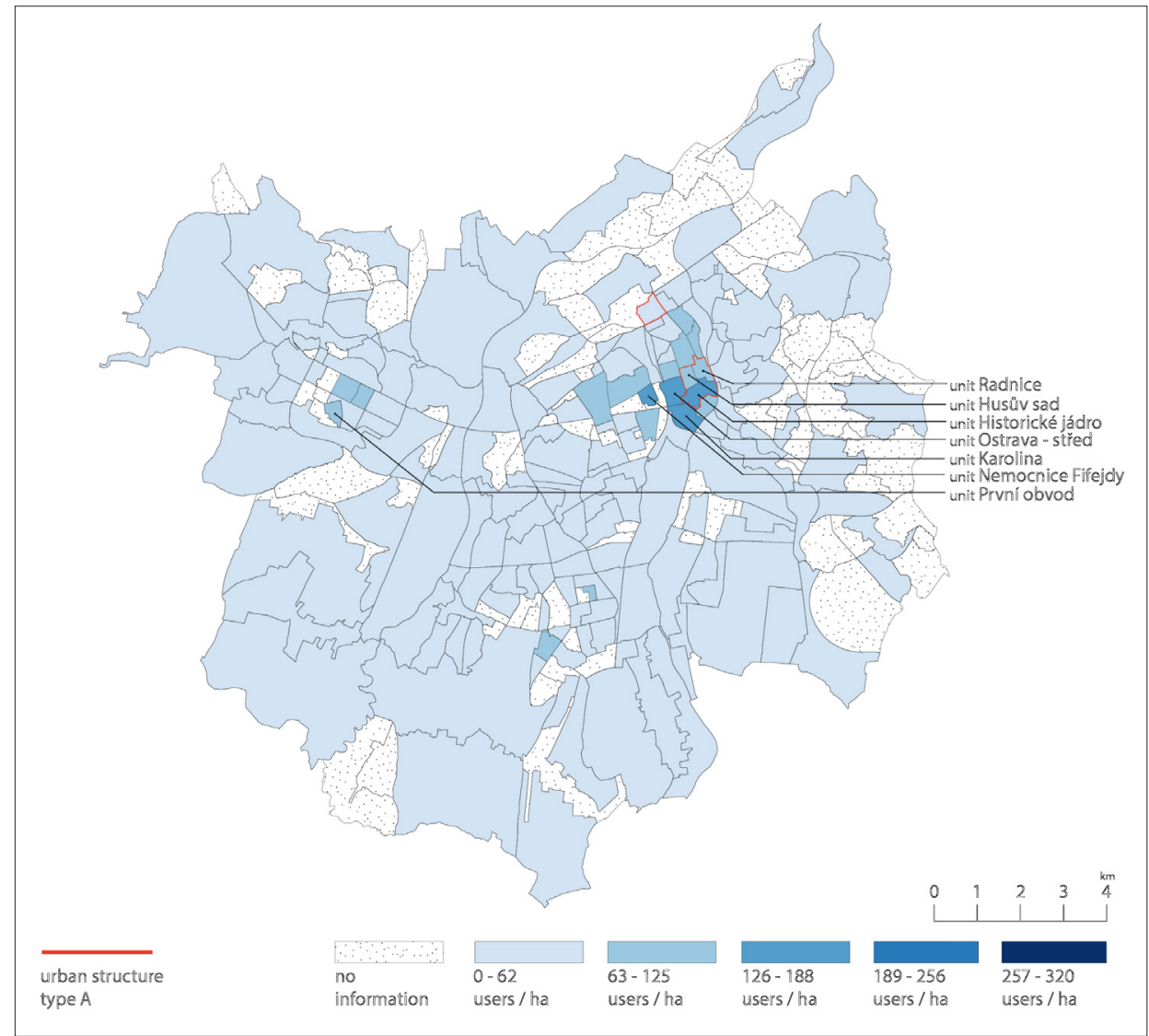

Fig. 3: Attractiveness of individual basic settlement units (ZSJ) in Ostrava during the day according to the mobile network operator, May 2018. Source: O2 Czech Republic, authors' elaboration

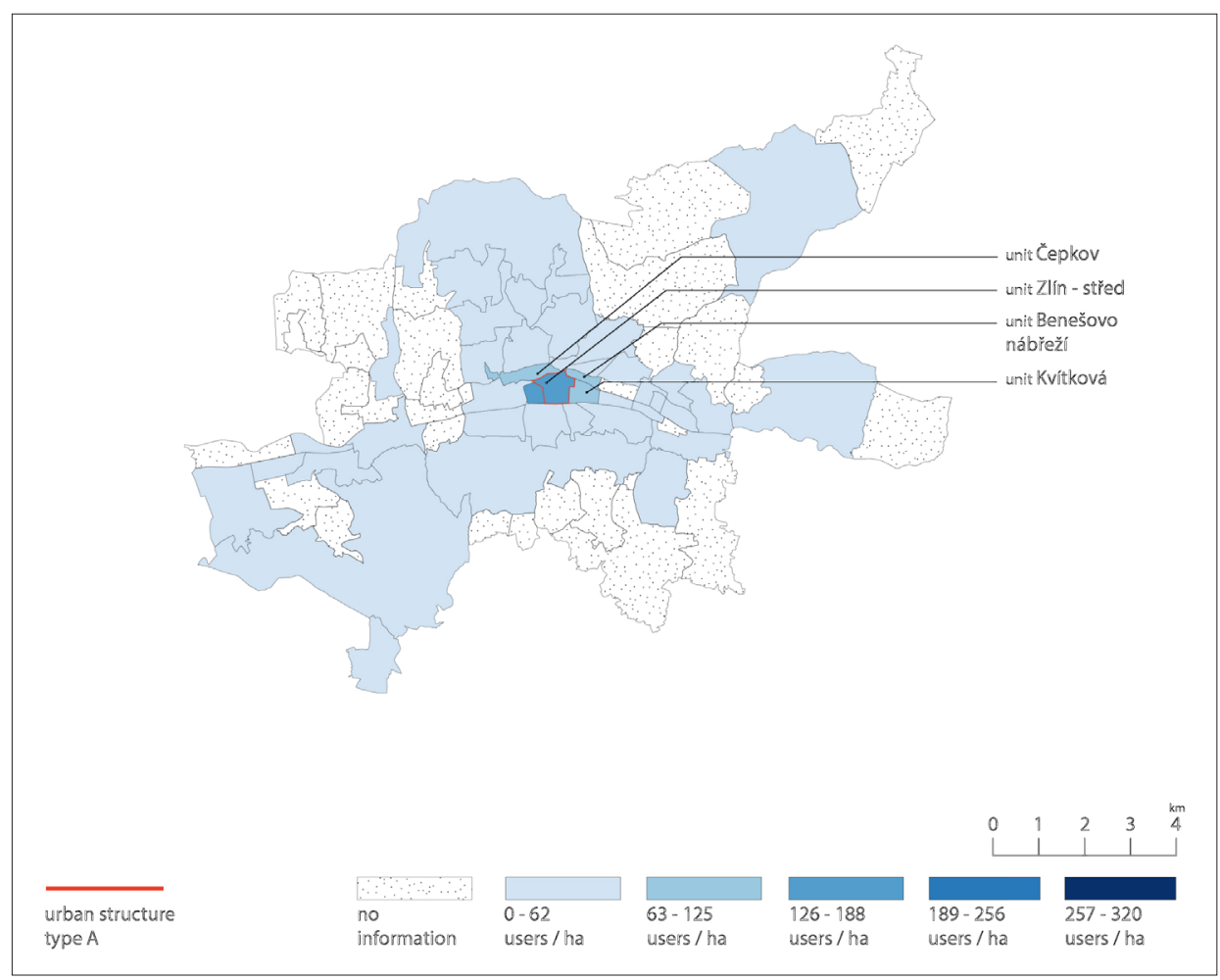

Fig. 4: The attractiveness of individual basic settlement units (ZSJ) in Zlin during the day according to the mobile network operator, May 2018. Source: O2 Czech Republic, authors' elaboration 


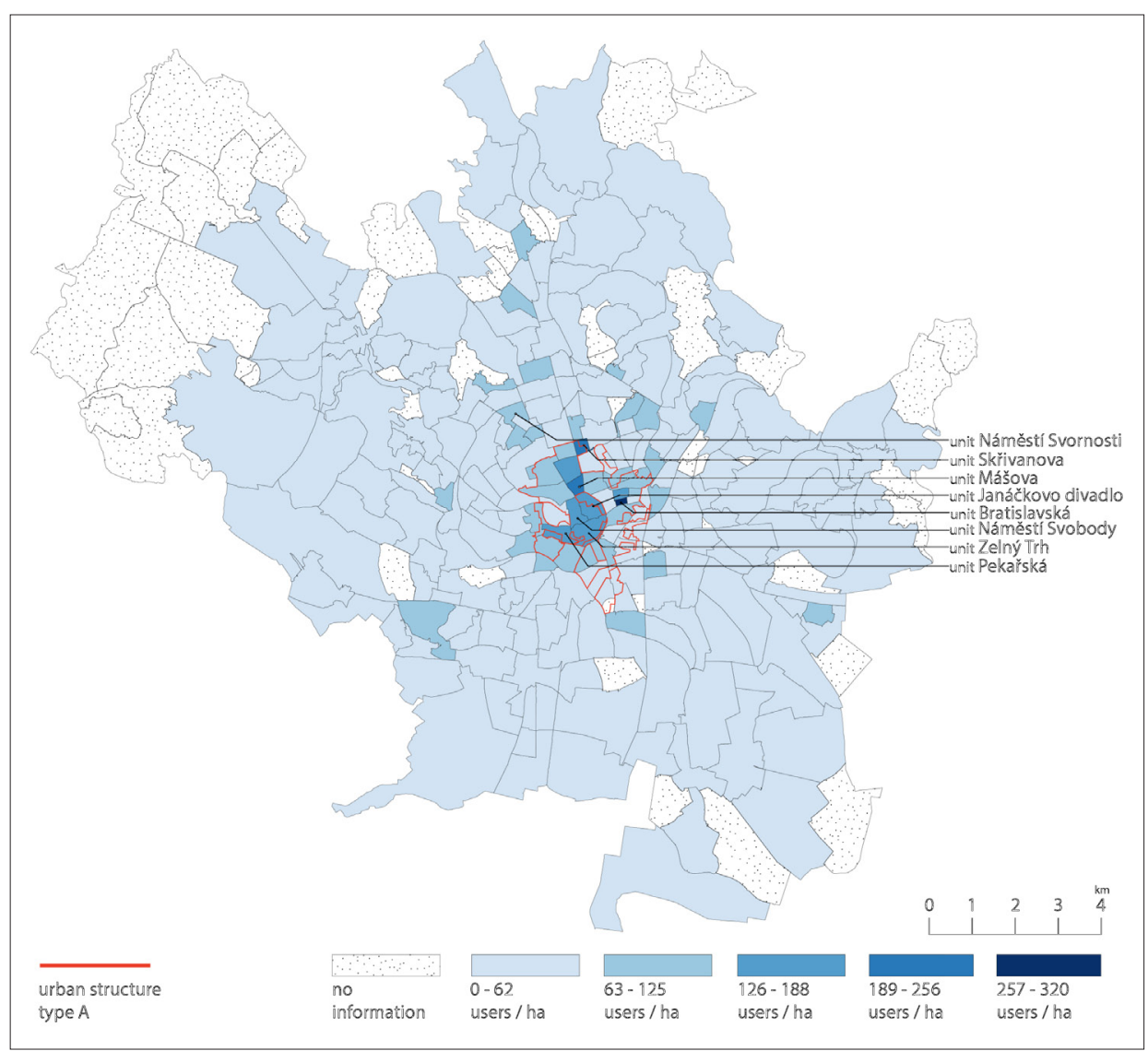

Fig. 5: The attractiveness of individual basic settlement units (ZSJ) in Brno during the night according to the mobile network operator, May 2018. Source: O2 Czech Republic, authors' elaboration

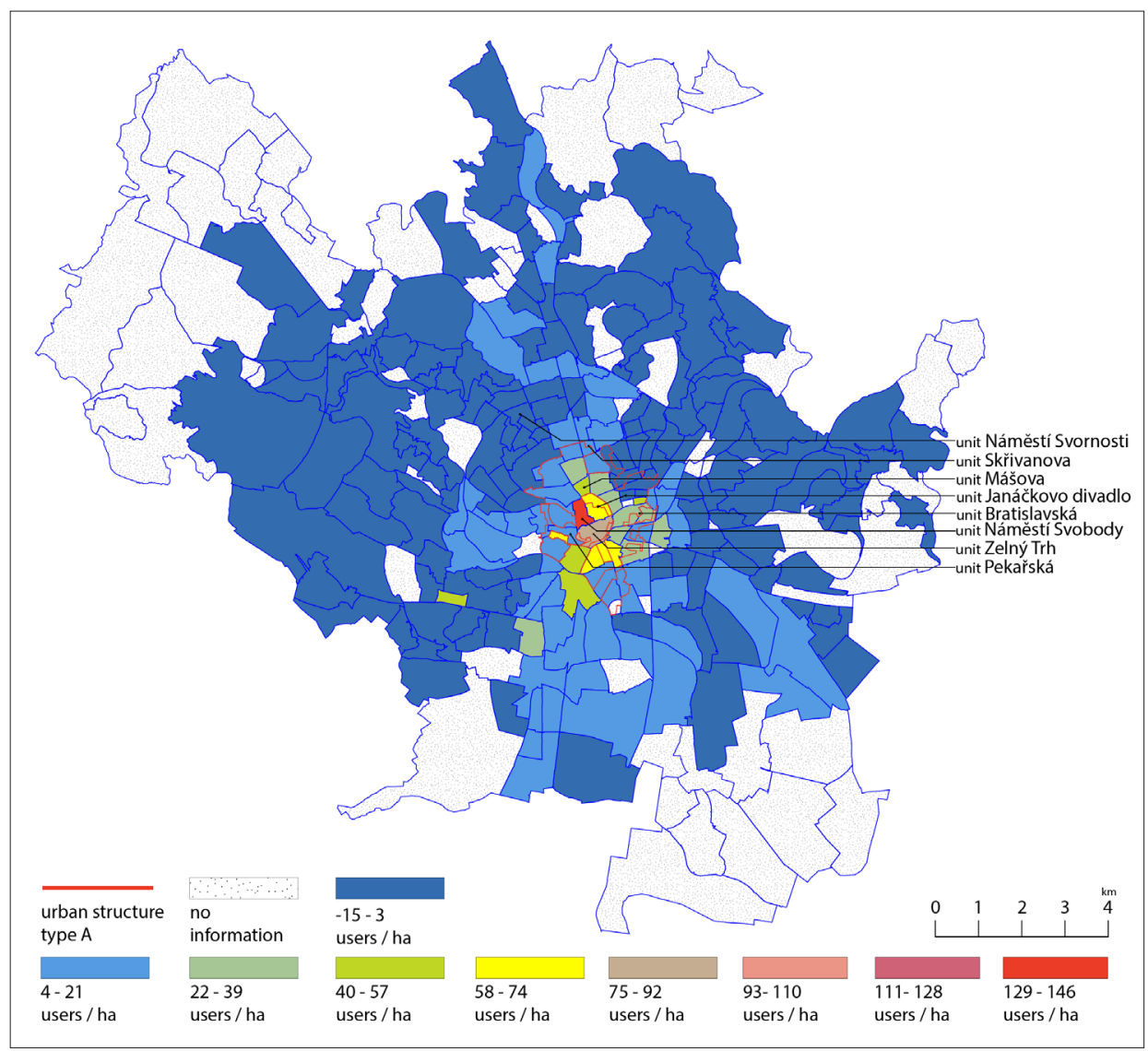

Fig. 6: Differences between the day and night attractiveness of individual basic settlement units (ZSJ) in Brno according to the mobile network operator, May 2018. Source: O2 Czech Republic, authors' elaboration 


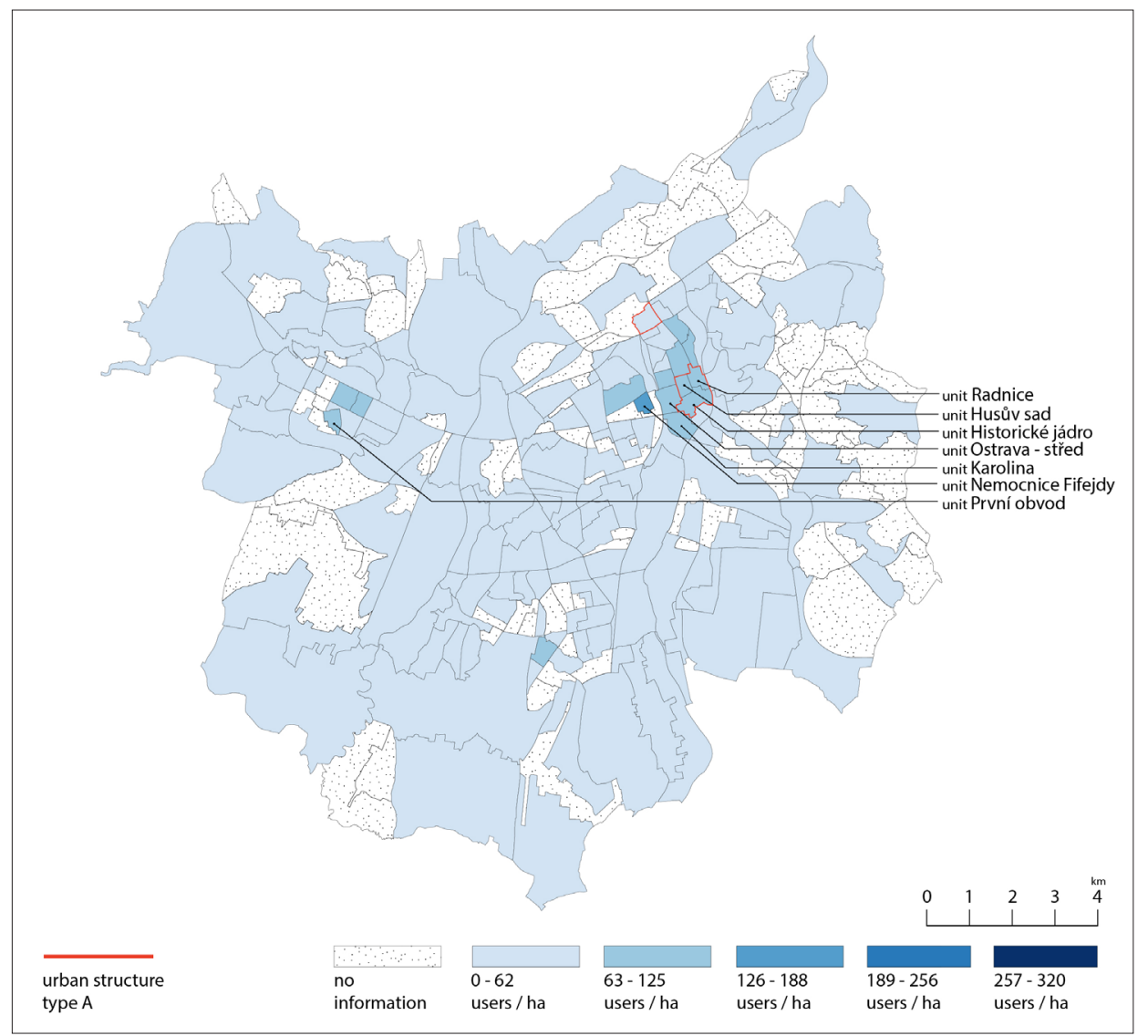

Fig. 7: The attractiveness of individual basic settlement units (ZSJ) in Ostrava during the night according to the mobile network operator, May 2018. Source: O2 Czech Republic, authors' elaboration

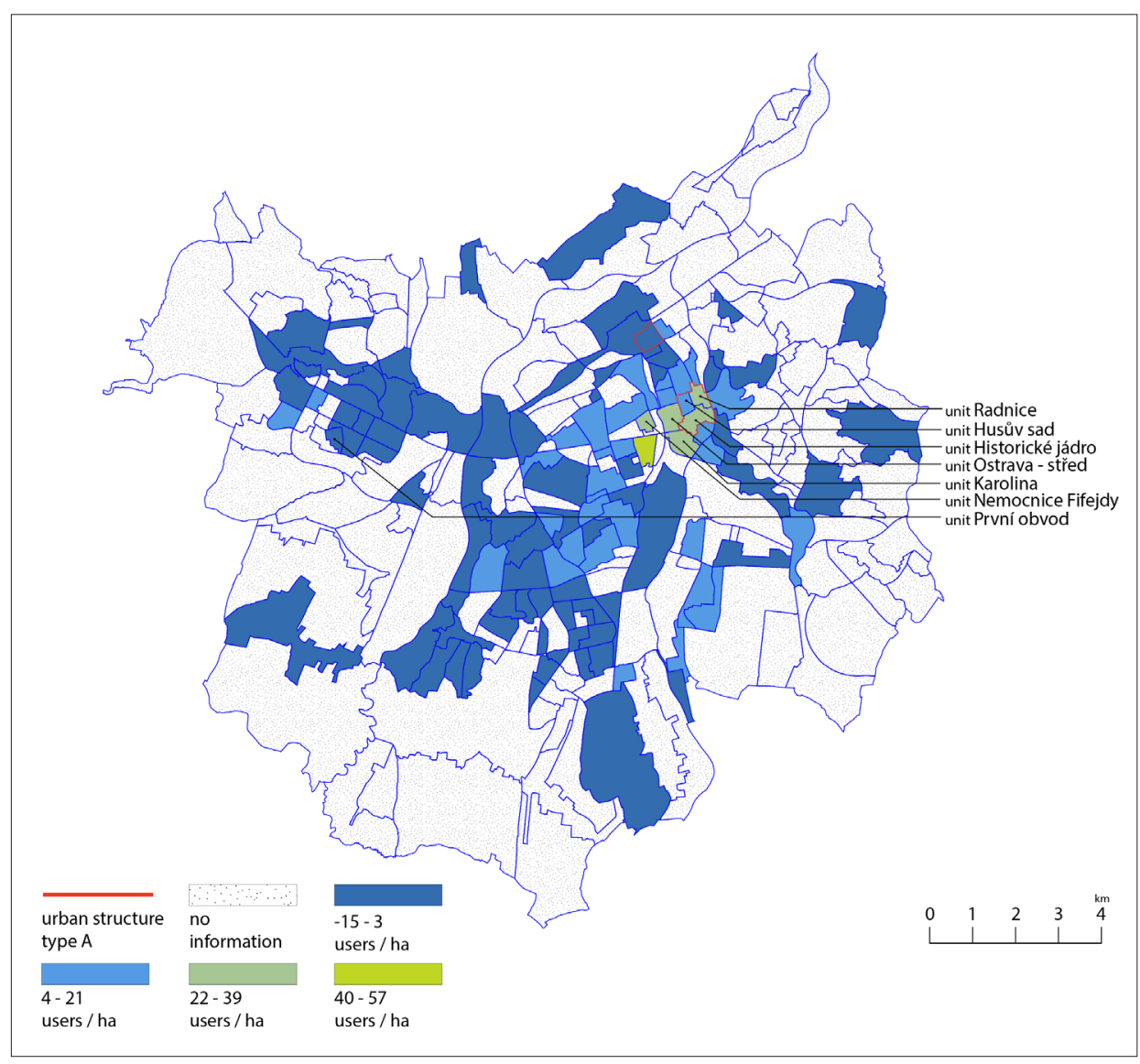

Fig. 8: Difference between the day and night attractiveness of individual basic settlement units (ZSJ) in Ostrava according to the mobile network operator, May 2018. Source: O2 Czech Republic, authors' elaboration 
lower importance of the city, and especially by the lower significance of the centre of Moravská Ostrava as a centre of the whole city.

The highest density of mobile phone users during the day in Zlín (see Fig. 4 above) can be seen in central parts and in units immediately surrounding the centre at 2 p.m., and in the evening in some inner-city parts. The historical core of old Zlín is not as large as in Brno or in Ostrava, and other parts of the inner city are multifunctional, combining residential and infrastructural functions and residences of various types, originating from different times.

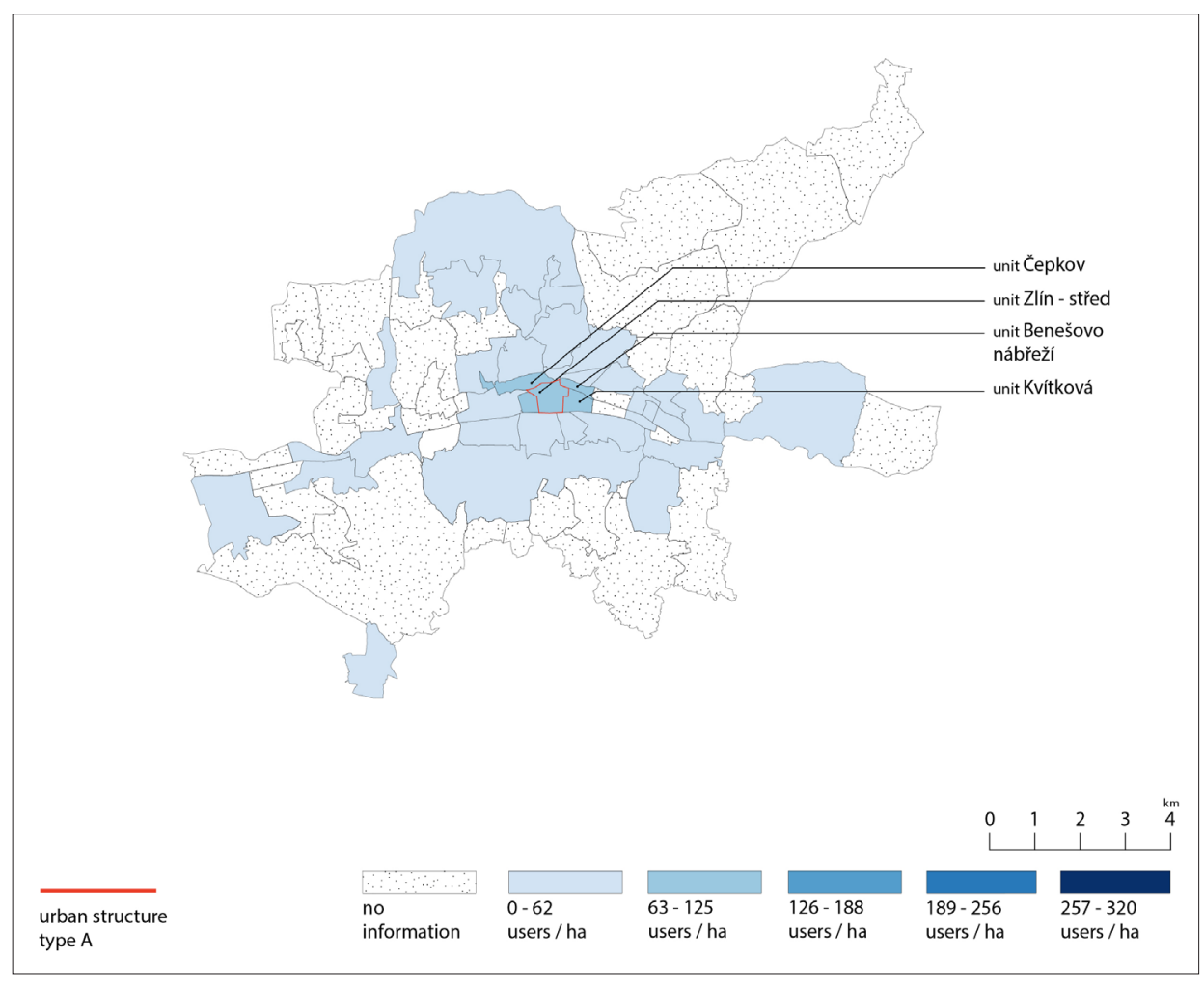

Fig. 9: The attractiveness of individual basic settlement units (ZSJ) in Zlin during the night according to the mobile network operator, May 2018. Source: O2 Czech Republic, authors' elaboration

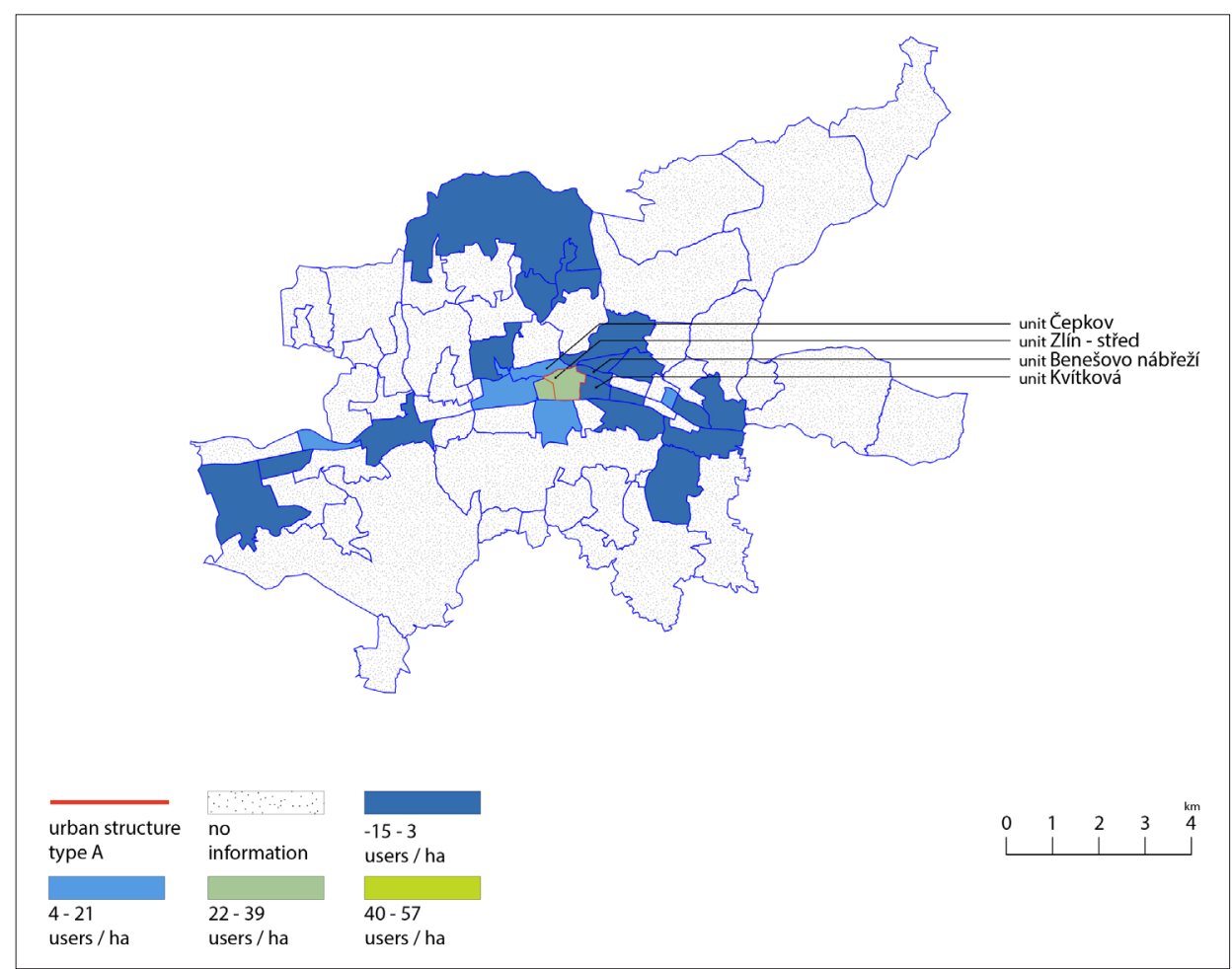

Fig. 10: Differences between the day and night attractiveness of individual basic settlement units (ZSJ) in Zlin according to the mobile network operator, May 2018. Source: O2 Czech Republic, authors' elaboration 


\subsection{Population distribution changes in Brno, Ostrava and Zlin during the night}

The highest density of mobile phone users in Brno at night (see Fig. 5) was observed in fact in the same localities as during the daytime. Of these units, however, the greatest decrease in attending people was found in the most central areas (Fig. 6). Logically, such a decrease should be even more demonstrated in the early morning (4 a.m.). On the contrary, the prefabs on the city outskirts exhibited an increased number of mobile phone users during the night. Nevertheless, this increase was relatively low (on average by 4 users/ha).

The highest density of night mobile phone users per ha in Ostrava (Fig. 7) was shown in the central parts of the city, which also recorded the greatest decrease - similar to Brno. In mono-functional residential areas, the increase was not significant (on average by 1 person/ha; Fig. 8).

The highest density of mobile phone users in Zlín during the night hours was observed in the same areas as during the daytime. Logically, the highest decrease of persons present during the night was found in the city centre (see Fig. 9). In Zlín, the situation at 4 a.m. did not differ from the night average - there are probably much fewer night clubs, shops and restaurants as compared with Brno and Ostrava. In the other central territorial units of mixed residential or non-residential character, the decrease of users did not occur at night (Fig. 10). Some increase of night-time users (2-8 persons per ha) was found in the mono-functional residential urban structures of all kinds: family houses, villas, apartment buildings. In the largest prefab neighbourhood of Zlín (Jižní svahy - Southern Slopes), however, the operation of mobile phones was identical both during the day and in the night time.

\subsection{Changes in mobile phone users in urban structures during the day and night}

The above maps (Figs. 1-10) show the numbers of users of mobile networks in basic settlement units of all three cities. Figure 11 presents the continual change in the number of users during the day in the different types of urban structures. The individual diagrams illustrate changes from four o'clock AM to ten o'clock PM, i.e. at the time when the cities live ( $x$-axis); in the remaining night hours, the number of users was constant.

Changes in the density of users are not expressed in the number of individuals per hectare but in relative values in percentage terms ( $y$-axis). While the data relating directly to the territorially demarcated units may be inaccurate in the territorial demarcation/geo-location distorted by the transmitters of mobile network operators, relative changes occurring in time do not suffer from such inaccuracies: in these situations, the use of data from mobile network operators appears the most beneficial.

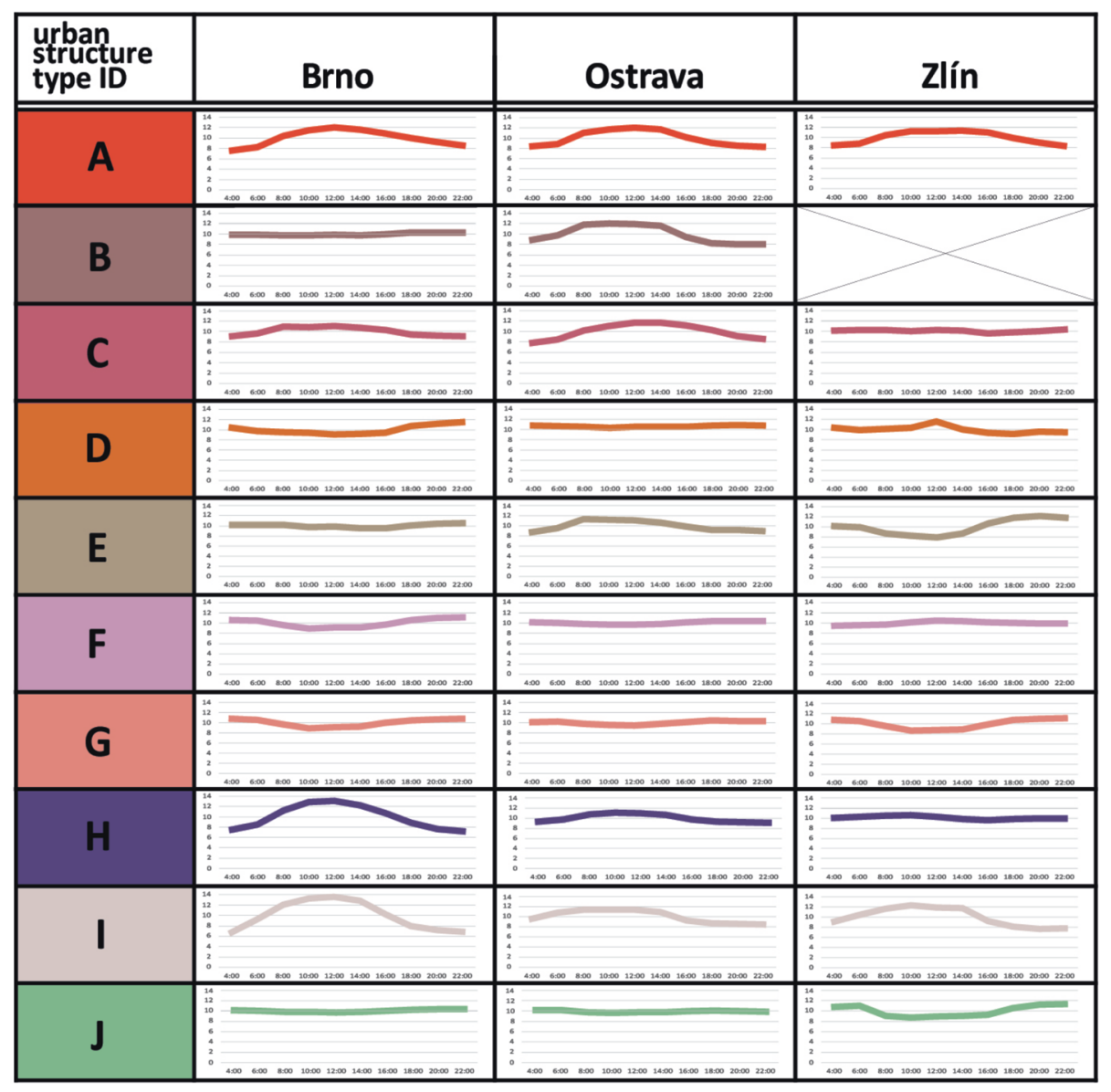

Fig. 11: Changes in the density of mobile phone users in the urban structure types of Brno, Ostrava and Zlin during the day. Source: O2 Czech Republic, authors' elaboration

Legend: Urban structure types: A - central block; B - suburban block; $C$ - unordered urban area; $D$-two-year plan buildings; $E$-villa quarters; $F$-prefab housing estates; $G$-family houses; $H$-public infrastructure; $I$-storage, manufacture, services; $J$-forests and parks. Note: The data represent all basic settlement units in the investigated cities with the dominant above-shown type of urban structure. 
It seems that the change in the density of phone users does not depend so much on spatial aspects of the concrete type of urban structure, but rather on the functional use of the area and whether the function of this area is of housing character or serves visitors. Logically, in practically all cities, the greatest daily fluctuations - daytime increases - are recorded in central areas (A), in areas with civic amenities (H) or manufacturing and administrative complexes with high numbers of employees (I). The studied cities do exhibit, however, some differences in the dynamics of user density change, following from the size and significance of the city and its inner layout. As the largest and most significant city, Brno exhibits the greatest density changes in the city centre and in the areas of manufacturing and civic amenities. Recording smaller daytime increases in the centre, the polycentric Ostrava shows, by contrast to Brno, higher day-time activities in the centres of city districts, which are often comprised of B type block structures. Zlín, with the predominant dwelling character of most structures and a minimal number of external visitors, exhibits the greatest night increases of mobile networks users. A special Zlín peculiarity is the high night activity in suburban woods (J), which is probably caused by inhabitants of summer cottages not returning home for the night. (In this context, it should also be mentioned that the number of users of mobile networks in such areas exceeds the number of inhabitants, according to the census).

Comparing details of the situation in the respective basic settlement units, we found out that considerable differences in the dynamics/rhythmicity of changes in the density of visitors can happen inside a single type of urban structure too. Figures 12-14 show the development of the number of persons, who are present in selected central and residential localities of the surveyed cities during the whole day. The data are related to the number of persons per hectare. In all cases, typical urban structures were chosen, in which houses are organised in more or less regular closed blocks. Figure 12 describes the situation in the poly-functional structures of historical cores; Figure 13 shows the situation in a wider urban centre (in Brno and Ostrava) with constructions from the turn of $18^{\text {th }}$ and $19^{\text {th }}$ centuries; and Figure 14 shows a block structure with the dominating residential function from about the middle of the last century, which can be found in the unbroken urbanised area away from urban centres. The situation represented by the basic urban units of Bratislavská and Hvězdová in Brno (Fig. 13) is atypical, as it has a high share of the Roma population.

The expected decrease of mobile phone users in the central areas at night was confirmed, but the number of users in the central areas of the cities remains surprisingly quite high, also at night. The residential quarters of the cities are not completely depopulated during the daytime either. Some extreme differences can be seen in Brno, where the city core attractiveness during the day is the largest of all studied cities. Such a situation reflects the concentric organisation of the urban structure in Brno, as well as a greater power of this city reaching beyond its regional borders. At the same time, the unattractiveness (depopulation) of residential parts situated on the city outskirts is shown in Figure 14. While the density of mobile phone users in these parts of Brno decreases, in Ostrava the decrease is insignificant and in Zlín it does not occur at all.

The situation in the above-mentioned locality of Bratislavská-Hvězdová with a large share of a culturally different population is interesting (Fig. 13). The

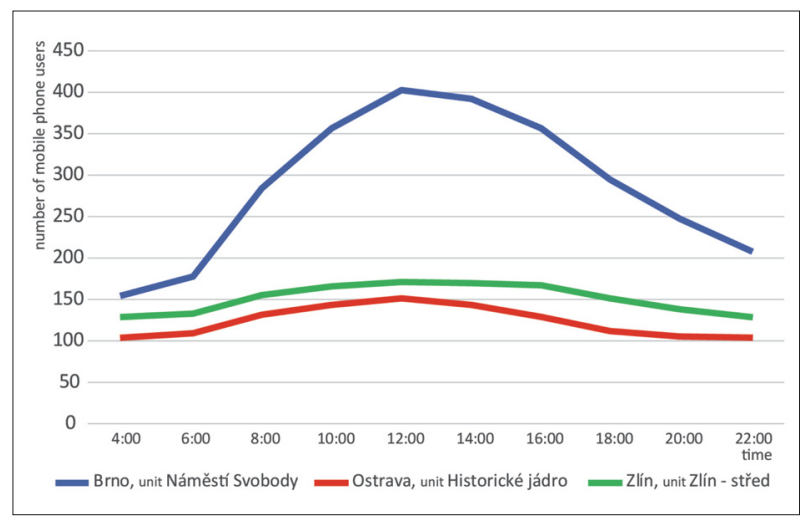

Fig. 12: Development in the density of mobile phone users in the historical cores of Brno, Ostrava and Zlin during the day (Náměstí Svobody Square in Brno, Historical Core in Ostrava, Zlin-Centre)

Source: O2 Czech Republic, authors' elaboration

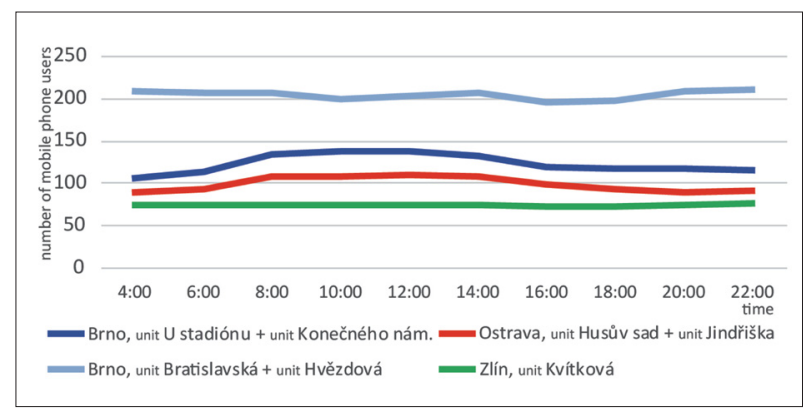

Fig. 13: Development in the density of mobile phone users in the wider centre localities of Brno, Ostrava and Zlin during 24 hours

Source: O2 Czech Republic, authors' elaboration

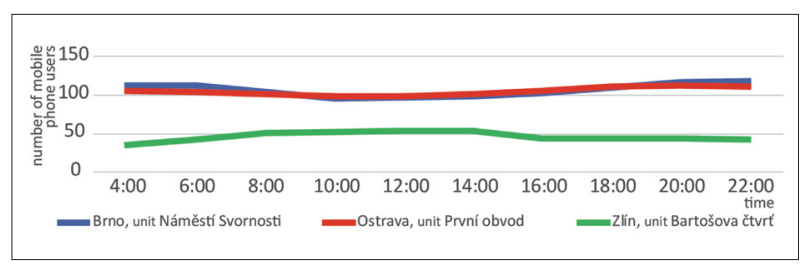

Fig. 14: Development in the density of mobile phone users in the residential localities of Brno, Ostrava and Zlin during 24 hours (Náměstí Svornosti Square in Brno, Pruní obvod District 1 in Ostrava-Poruba, Bartošova čtvrt' Quarter in Zlín)

Source: O2 Czech Republic, authors' elaboration

concentration of mobile phones (hence the concentration of people) is very high as compared to other parts of the city, although there are considerably fewer social infrastructure facilities and other central urban functions in this area. In addition, more mobile phone users are recorded there at night than during the day.

The number of phone users present at night in the attractive historical cores and in the quarters inhabited by the Roma population in Brno significantly exceeds the number of permanent residents. Whereas in the case of the historic cores, this phenomenon is likely to indicate flats that are rented for a short-term to tourists or students, in the case of the Bratislavská-Hvězdová locality, there are probably people who have not been registered in the population census (relatives of Roma residents) (see Tab. 1). 
The comparison of mobile phone users at four o'clock in the morning also indicates that in the wider urban centre more flats are rented than in the prefabs.

\section{Conclusions: Challenges and possibilities of monitoring of users in the urban space}

In summary, in all three case study cities, the highest concentrations of mobile network users were recorded in the historic city centres, both during the day and at night. At the same time, however, city centres (excluding monofunctional production, administrative and commercial parks) recorded the largest differences between the numbers of day and night mobile phone users. The historic cores exhibited a high number of users despite a declining number of permanent residents and the outflow of many business activities to new premises on the city outskirts. With the general economic improvement, rising land values and spatial development policies aimed at deconcentration, more people move away from the core areas than move in (Jones, 2000), and similar processes are observed in the largest Moravian cities. It turns out that the picturesque compact and multifunctional structure of the historic core is attractive to visitors by itself, even when the core is relatively small, and central functions are largely concentrated in a new centre outside the original historic core, which is the case of Zlín. Despite this common feature - attractiveness of a compact historic structure - one fundamental difference between the monitored cities was confirmed, which lies in their arrangement. The historic core and the city centre in a concentric layout, such as in Brno, is more important and more attractive to visitors.

The high number of night users of the mobile network in the historic centres of all three cities, even in settlement units with no hotels and night clubs (Tab. 1) is somewhat surprising with respect to an ever-decreasing number of permanent residents in central urban areas - at night, when there are no tourists or employees. This possibly means there is still a relatively large number of statistically not registered residents in the city cores. The observed data say nothing about the social structure of these tenants, i.e. whether they are temporarily accommodated students and young employees or tourists or unregistered members of social/ethnic groups, which could be a sign of the (unwanted) degradation of the urban structure. As Wittmann and Kopáčik (2019) show, however, high prices of real estate in the historic centres of the monitored cities rather suggest a high attractiveness of the studied central localities and that the tenants are relatively wealthy.

With a high share of students and young urban professionals, who are present in the city with the most developed quaternary functions, Brno has a much higher number of temporary residents in comparison with cities that do not have such types of activities. Brno city population is estimated to be about 160,000 persons more than the statistically recorded number of permanent residents (Brno, 2014). This fact was first discovered through the exceeded capacity of the municipal wastewater treatment plant, i.e. not by demographers or statisticians, and it has been confirmed by other technical infrastructures, for example by the number of persons paying for waste disposal.

The above research results lead to the following conclusions. The density of the users of mobile networks, i.e. the number of persons in the area, depends on: [1] city size; [2] on the urban structure and on the relative position of individual functional city areas; [3] on the course of contemporary urban processes such as suburbanisation or gentrification; and [4] on quaternary functions which are mostly post-productive: education, health care, commerce, tourism, and entertainment. Universities, hospitals and commercial centres play the most important role in the daytime rhythm. These aspects discriminate between the three cities under investigation

Of course, the suitability of the methodology used in this study can be discussed. One of the deficiencies in the open mobile phone data consists in the recorded numbers reduced due to data aggregation and anonymization using 100 users as a limit.

Another problem is the accuracy of up to 100 metres of user signal geo-locations. This could mean that, especially in the city outskirts, phone users can be classified within settlement units different from those they belong to according to the Czech Statistical Office. We agree with the opinion of Soukup (2017), who says that mobile phone data do still have problems with the accuracy of collected user numbers, due to their aggregation to the total number of inhabitants. For such differences, mobile phone data

\begin{tabular}{lcc}
\hline Locality & $\begin{array}{c}\text { Residents per ha } \\
\text { (census 2011) }\end{array}$ & $\begin{array}{c}\text { Users of mobile phones } \\
\text { per ha at 4 a.m. }\end{array}$ \\
\hline Historic Core in Brno & 55 & 142 \\
Historic Core and adjacent parts in Ostrava & 85 & 103 \\
Historic Core in Zlín & 68 & 128 \\
Wider centre in Brno: U stadiónu, Konečného náměstí Sq. & 141 & 111 \\
Wider centre in Brno: Bratislavská and Hvězdová Streets & 179 & 223 \\
Wider centre in Ostrava & 132 & 85 \\
Wider centre in Zlín & 89 & 75 \\
Prefabricated estate Bystrc in Brno & 81 & 12 \\
Prefabricated estate Poruba in Ostrava & 108 & 37 \\
Prefabricated estate Southern Slopes in Zlín & 94 & 13 \\
\hline
\end{tabular}

Tab. 1: Residents versus mobile phone users in some parts of the studied cities during the night Source: O2 Czech Republic, authors' calculations

Note: Due to a possible discrepancy between the borders of basic settlement units and the areas of telecommunication services, several units were calculated together 
should be considered as additional information, where careful calibration and caution in usage are needed. The inaccuracy mainly concerns the absolute number of users in the settlement unit. If we monitor the dynamics, changes in the number of users during a unit of time, however, the data appear to be relevant.

The data from the mobile network operator give a picture of day and night patterns of users' movement within the city, which can be considered in creating a more dynamic picture upon their weekly renewal, than data provided by the Czech Statistical Office. The number of mobile network users seems to be another very useful urban indicator, in addition to population density and stop index or floor area index. Nevertheless, data provided in the open format should be used carefully at least in the format they are published on the 02 API website. There is a huge potential for the use of mobile phone data by city planners after a robust data calibration in the future, and it would be interesting to compare the mobile phone data information with the population Census coming up in 2021.

\section{Acknowledgement}

This paper is a result of a project of the Grant Agency of the Czech Republic: No. 17-26104S: "The influence of urban structure type and location on the sustainable spatial development".

\section{References:}

ABRAMSON, D. M. (2009): Obsolence and the fate of Zlín. In: Klingan, K. [ed.]: A Utopia of modernity: Zlín revisiting Bata's functional city (pp. 157-169). Berlin, Jovis Verlag.

BIERZYŃSKI, A., GRABKOWSKA, M., HAASE, A., KLUSÁČEK, P., MAAS, A., MAIR, J., MARTINÁT, S., SAGAN, I., STEINFÜHRER, A., VAISHAR, A., WECLAWOWOCZ, G., ZAPLETALOVÁ, J. (2011): Łódź, Gdańsk, Brno and Ostrava and their inner cities: Urban and demographic development during post-socialism. In: Haase, A., Steinführer, A., Kabisch, S. Grossmann, K., Hall, R. [eds.]: Residential Change and Demographic Challenge (pp. 101-142). Farnham, Ashgate.

BRAUER, R., DYMITROW, M. (2017): Human geography and the hinterland: The case of Thorsten Hägerstrand's 'belated' recognition. Moravian Geographical Reports, 25(2): 74-84.

BUS Architektur \& Friends (2003). Urban Unconscious. Buenos Aires, Wien: Casa Editrice Libria.

COFFEE, N. T., LANGE, J., BAKER, E. (2016): Visualising 30 years of population density changes in Australia's major capital cities. Australian Geographer, 47(4): 51-525.

CZECH STATISTICAL OFFICE (2017): Demografický vývoj ve městech Jihomoravského kraje v roce 2017 [online]. [cit. 09.08.2018]. Available at: https:// www.czso.cz/csu/xb/demograficky-vyvoj-ve-mestechjihomoravskeho-kraje-v-roce-2017

DEVILLE, P., LINARD, C., MARTIN, S., GILBERT, M., STEVENS, F. R., GAUGHAN, A. F., BLONDEL, V. B., TATEM, A. J. (2014): Dynamic population mapping using mobile phone data. Proceedings of the National Academy of Sciences of the USA, 111(45): 15888-15893.
EDENSOR, T. [ed.] (2010): Geographies of Rhythm. Nature, Place, Mobilities and Bodies. London, Routledge.

ELLEGÅRD, K. (2019): Introduction: The roots and diffusion of time-geography. In: Ellegård, K. [ed.]: Time geography in the global context (pp. 1-18). London, Oxon Academics.

FERNANDEZ-MALDONADO, A. M. (2012): ICT and Spatial Planning in European Cities: Reviewing the New Charter of Athens. Built Environment, 38(4): 469-483.

GEHL, J. (2011). Life between buildings: using public space. Washington, Island Press.

GRAUWIN, S., SOBOLEVSKY, S., MORITZ, S., GÓDOR, I., RATTI, C. (2014): Towards a comparative science of cities: using mobile traffic records in New York, London and Hongkong. In: Helbich, M., Jokar Arsanjani, J., Leitner, M. [eds.]: Computational approaches for urban environment (pp. 363-387). Cham, Springer.

GSM web (2018): Interaktivní mapa BTS, [online]. GSM web website [cit. 19.12.2018]. Available at: https://www.gsmweb.cz/mapa/index. php?go $=1 \&$ op $=$ all\&filter $=$ okres\&okres $1=\mathrm{BM}$ )

HNILIČKA, P. (2012). Sídelní kaše: otázky k suburbánní výstavbě kolonií rodinných domů: urbanismus do kapsy. Brno, Host.

HORÁKOVÁ, E. (2018): Sociologická a urbanistická analýza města použitím dat mobilních operátorů. In: Palacký, J., Dokoupilová-Pazderková, K. [eds.]: PhD Research Sympozium 2018 (pp. 6-11). Brno, University of Technology in Brno.

HORSKÁ, P., MAUR, E., MUSIL, J. (2002): Zrod velkoměsta. Urbanizace českých zemí a Evropa. Praha - Litomyšl, Paseka.

IBRNO (2014): Co vše o Brně prozrazují statistiky [online]. iBrno website [cit. 17.05.2019]. Available at: https:// www.ibrno.cz/brno/59801-co-vse-o-brne-prozrazujistatistiky.html

IPR (2016): Strategický plán hlavního města Prahy. Praha, Magistrát hlavního města Prahy.

JACOBS, J. (1961): The death and life of great American cities. New York, Random House.

JACOBS, J. (1970): The economy of cities. New York, Random House.

JÄRV, O., TENKANEN, H., SALONEN, M., AHAS, R., TOIVONEN, T. (2018): Dynamic cities: location-based accessibility modelling as a function of time. Applied Geography, 95: 101-110.

JEMELKA, M., ŠEVEČEK, O. (2013): The Utopian Industrial City: The Case of the Bata City of Zlín (Republic of Czechoslovakia). In: Zimmermann, C. [ed.]: Industrial Cities (pp. 235-262). New York, Campus Verlag.

JONES, T. L. (2000): Compact city policies for megacities. In: Jenks, M., Burgess, R. [eds.]: Compact Cities (pp. 37-52). London, Routledge.

KOPÁČIK, G., VAISHAR, A. (2020): Residential function dynamics in the urban territory: the case of selected Moravian cities. In: Peřinková, M. [ed.]: Architecture in perspective 2020 (pp. 152-157). Ostrava, VŠB - TU Ostrava. 
KOPÁČIK, G., KILNAROVÁ, P. (2018): Schopnost různých typů urbanistických struktur středoevropských měst ovlivňovat teplotu vzduchu / The ability to influence air temperature in different types of the urban structure of middle European cities: In: Peřinková, M. [ed.]: Architecture in perspective 2018 (pp. 256-260). Ostrava, VŠB - TU Ostrava.

KUBÍČEK, P., KONEČNÝ, M., STACHOŇ, Z., SHEN, J., HERMAN, L., ŘEZNÍK, T., STANĚK, K., ŠTAMPACH, R., LEITGEB, S. (2019): Population distribution modelling at fine spatio-temporal scale based on mobile phone data. International Journal of Digital Earth, 12(11): 1319-1340.

KUČA, K. (2000): Brno - vývoj města, předměstí a připojených vesnic. Brno, Baset.

LAGER, D., VAN HOVEN, B., HUIGEN. P. (2016): Rhythms, ageing and neighbourhoods. Environment and Planning A: Economy and Space, 48(8): 4565-1580.

LAGUERRE, M. S. (2003) Conclusion: Chronopolis and Metropolis. In Laguerre, M. S. [ed.]: Urban Multiculturalism and Globalization in New York City (pp. 141-142). London, Palgrave Macmillan.

LAITINEN, H., LAHTEENMAKI, J., NORDSTROM, T. (2001). Database correlation method for GSM location. In: IEEE VTS $53^{\text {rd }}$ Vehicular Technology Conference, Spring 2001 (pp. 2504-2508). Picsataway, NJ, IEEE.

LEFEBVRE, H. (2004): Rhytmanalysis: Space, Time and Everyday Life. London/New York, Continuum.

LOUAIL, T., LENORMAND, M., CANTU ROS, O. G., PICORNELL, M., HERRANZ, R., FRIASMARTINEZ, E., RAMASCO, J. J., BERTHELEMY, M. (2014): From mobile phone data to the spatial structure of cities. Scientific Reports, 4: 5276.

MALLESON, N., ANDRESEN, M. A. (2015): Spatio-temporal crime hotspots and the ambient population. Crime Science, 4(10): 1-8.

MARQUES, S. C. R., FERREIRA, F. A. F., MEIDUTEKAVALIAUSKIENE, I., BANAITIS, A. (2018): Classifying urban residential areas based on their exposure to crime. A constructivist approach. Sustainable Cities and Society, 39: 418-429.

MATYÁŠOVÁ, J., BOUŠKOVÁ, L. (2019): Obytné soubory \& spokojenost obyvatel: vybrané lokality z Brna a Vídně. Brno, Vysoké učení technické v Brně.

MELS, T. [ed.] (2004): Reanimating place. A geography of rhythms. London, Routledge.

MULÍČEK, O., OSMAN, R., SEIDENGLANZ, D. (2016): Time-space rhythms of the city - the industrial and postindustrial Brno. Environment and Planning A: Economy and Space, 48(1): 115131.

MULÍČEK, O., OSMAN, R. (2018): Rhythm of urban retail landscapes: Shopping hours and the urban chronotopes. Moravian Geographical Reports, 26(1): 2-13.

NADAI, M. de, STAIANO, J., LARCHER, R., SEBE, N., QUERCIA, D., LEPRI, B. (2016): The death and life of great Italian cities: A mobile phone data perspective. In: Proceedings of the $25^{\text {th }}$ International Conference on World Wide Web (pp. 413-423). Montreal, Université du Quebec.

NEUHAUS, F. (2015): Urban Rhythms. In: Neuhaus, F. [ed.]: Emergent Spatio-temporal Dimensions of the City (pp. 1-11). Cham, Springer.
NEUMAN, M. (2005): The Compact City Fallacy. Journal of Planning Education and Research, 25(1): 11-26.

NOVÁK, J., TEMELOVÁ, J. (2012): Everyday life and spatial mobility of young people in Prague: a pilot study using mobile phone location data. Czech Sociological Review, 48(5): 911-938.

O2 (2018): O2 Liberty API [online]. O2 website [cit. 09.08.2018]. Available at: https://www.o2.cz/podnikatel/ liberty-api/

OSMAN, O., MULÍČEK, O. (2017): Urban chronopolis: Ensemble of rhythmized dislocated places. Geoforum, 85: 46-57.

PASQUI, G. (2016): Population and rhythms in contemporary cities. In: Pucci, P., Colleoni, M. [eds.]: Understanding Mobilities for Designing Contemporary Cities (pp. 4963). Cham, Springer.

REID-MUSSON, E. (2017): Intersectional rhythmanalysis: power, rhythm, and everyday life. Progress in Human Geography, 42(6): 881-897.

RUMPEL, P., SLACH, O. (2012): Is Ostrava a shrinking city? Czech Sociological Review, 48(5): 859-878.

SILM, S., AHAS, R., NUGA, M. (2013): Gender differences in space-time mobility patterns in a post-communist city: a case study based on positioning in the suburbs of Tallinn. Environment and Planning B: Urban Analytics and City Science, 40(5): 814-828.

SIMONSEN, K. (2004): Spatiality, temporality and the construction of the city. In: Bćrenholz, O., Simonsen, K. [eds.]: Space Odysseys (pp. 43-63). London, Routledge.

SLACH, O., NOVÁČEK, A. (2017): Pokles atraktivity center měst v Česku a možná řešení [online]. URBACT Česká republika [cit. 30.10.2020]. Available at: https:// www.researchgate.net/publication/319503270_Pokles atraktivity_center_mest_v_Cesku_a_mozna_reseni.

SMITH, R. J., HALL, T. (2013): No time out: mobility, rhythmicity and urban patrol in the twenty-four hours city. Sociology Review, 61: 89-108.

SOUKUP, M. (2017): Co nám prozradí data z mobilů? ArcRevue, 25(2): 10-13.

STEENBRUGGER, J., TIRANOS, E., NIJKAMP, P. (2015): Data from mobile phone operators: a tool for smarter cities? Telecommunication Policy, 39(3-4): 335-346.

ŠVEDA, M., BARLÍK, P. (2018): Daily commuting in the Bratislava metropolitan area: case study with mobile positioning data. Papers in Applied Geography 4(4): 409-423.

SÝKORA, L., OUŘEDNÍČEK, M. (2007): Sprawling postcommunist metropoles: commercial and residential suburbanization in Prague and Brno, the Czech Republic. In: Razin, E., Dijst, M., Vázquez, C. [eds.]: Employment deconcentration in European metropolitan areas (pp. 209-233). Dordrecht, Springer.

SÝKORA, L., KAMENICKÝ, J., HAUPTMANN, P. (2000): Changes in the spatial structure of Prague and Brno in the 1990s. Acta Universitatis Carolinae Geographica, 35(1): 61-76.

VACKOVÁ, B., GALČANOVÁ, L. (2009): The project Zlín: A life in a materialized Utopia. Urban People, 11(2): 311-337. 
VAISHAR, A. (2002): Population development in the Ostrava region: Some aspects and current trends. Moravian Geographical Reports, 10(2): 28-36.

WHITEHEAD, S., MAILLEY, J., STORER, I., MCCARDLE, J., TORRENS, G., FARRELL, G. (2008): In safe hands: A review of mobile phone anti-theft designs. European Journal on Criminal Policy and Research, 14: 39-60.
WITTMANN, M. KOPÁČIK, G. (2019): Ovlivňuje urbanistická struktura ekonomii územního rozvoje? Případové studie v Brně, Ostravě a Zlíně. Regionální rozvoj mezi teorií a praxí, 2: 66-77.

WITTMANN, M. (2017): Mezi domy, mezi lidmi? Význam volných prostorů pro udržitelný urbánní rozvoj. Brno, Akademické nakladatelství CERM.

\section{Please cite this article as:}

KOPÁČIK, G., VAISHAR, A., ŠIMARA, E. (2021): The dynamics of population distributions in cities based on daily mobile phone operations: A case study of some Moravian cities. Moravian Geographical Reports, 29(1): 71-86. Doi: https://doi.org/10.2478/mgr-2021-0006 